\title{
SURFACE ENERGY BALANCE AFFECTS GAS EXCHANGE OF THREE SHRUB SPECIES
}

\author{
by Thayne Montague ${ }^{1}$, Roger Kjelgren ${ }^{2}$, and Larry Rupp ${ }^{3}$
}

\begin{abstract}
We investigated the energy balance of vegetative and nonvegetative surfaces and gas exchange for 3 shrub species growing over each surface. During a 1-week period, incoming short-wave radiation, surface and soil temperature, and soil heat flux for turf and pine-bark mulch surfaces were gathered. Air temperature and relative humidity at 2 heights over each surface were also measured. Mulch surface and air temperatures were warmer and soil temperature below mulch was cooler than turf throughout each day. Relative humidity varied with height above turf, but each height was comparable over mulch. For the majority of each day, soil heat flux below turf was greater than mulch. Dawn-to-dusk measurements of stomatal conductance, leaf temperature, and water loss for containerized skunkbush sumac (Rhus trilobata), spreading euonymus (Euonymus kiautschovicus 'Manhattan'), and redosier dogwood (Cornus sericea) were measured. Shrubs in mulch had higher leaf temperatures and greater leaf-to-air vapor pressure differences than shrubs in turf. Rhus trilobata had greater stomatal conductance and water loss in turf than mulch. However, for $E$. kiautschovicus and $C$. sericea, there were no differences in stomatal conductance or water loss between surface treatments. Midday photosynthetic rate was generally greatest for shrubs over turf. Shrub gas exchange differed according to how stomata responded to the leaf-toair vapor pressure difference over each surface.

Keywords. Rhus trilobata; Euonymus kiautschovicus 'Manhattan'; Cornus sericea; microclimates; gas exchange; leaf-to-air vapor pressure difference; water loss; urban landscape
\end{abstract}

Nonvegetative and vegetative urban landscape surfaces create distinctive microclimates (Whitlow and Bassuk 1987; Kjelgren and Clark 1992). A surface receiving solar radiation can disperse energy in different ways: warm the air above it by convection, conduct energy into the soil, convert energy to latent heat during transpiration, or reradiate energy as long-wave radiation (Doll et al. 1985). Because of the lack of transpirational cooling, heat convection and long-wave radiation from nonvegetative surfaces releases large amounts of energy into the air (Whitlow and Bassuk 1987). These factors have been found to increase air temperature and decrease relative humidity in urban areas (Miller 1980; Whitlow and Bassuk
1988; Kim 1992; Kjelgren and Clark 1992). Leaves of woody plants placed over nonvegetative surfaces intercept more convected and long-wave energy than plants over a vegetative surface (Whitlow and Bassuk 1987). Consequently, plants over nonvegetative surfaces have higher leaf temperatures (Whitlow and Bassuk 1988) and are exposed to greater evaporative demand (high leaf-to-air vapor pressure difference) than plants over vegetative surfaces (Kim 1992; Whitlow and Bassuk 1987). How transpiration is influenced by this increased evaporative demand depends on the extent to which a plant regulates stomatal opening (Farquhar 1978; Turner et al. 1984; Choudhury and Monteith 1986; Jarvis and Mcnaughton 1986). To regulate transpiration, stomata of many woody plants close when leaf-to-air vapor pressure differences (LVPD) are high (Turner et al. 1984; Choudhury and Monteith 1986). Plants that maintain open stomata dissipate more energy through transpirational evaporative cooling but use more soil water. Plants that close their stomata lose less water, but limit photosynthesis and increase respiration due to higher leaf temperatures (Kartusch 1983; Kjelgren and Clark 1993).

Depending upon species and location, woody landscape plants in urban environments may have increased (Miller 1980; Halverson and Potts 1981; Potts and Herrington 1982; Zajicek and Heilman 1991) or decreased (Kjelgren and Clark 1993) water loss. Dawn-to-dusk stomatal conductance and transpiration for sweetgum (Liquidambar styraciflua) trees in an urban plaza in Seattle, Washington, were lower than sweetgum trees in a nearby park (Kjelgren and Clark 1993). Zajicek and Heilman (1991) reported that crape myrtle (Lagerstroemia indica) cultivars placed over pinebark mulch had higher stomatal conductance during the morning when compared to plants over turf or bare soil. However, as LVPD increased in 
the afternoon, stomatal conductance for plants over mulch was comparable to plants over turf and bare soil. Because of greater morning stomatal conductance, daily water use was greater for plants over mulch when compared to plants over turf and bare soil (Zajicek and Heilman 1991). Transpiration rates for honeylocust (Gleditsia triacanthos inermis) and green ash (Fraxinus pennsylvanica) trees in urban settings also increased when compared to trees in rural sites (Halverson and Potts 1981; Potts and Herrington 1982; Whitlow and Bassuk 1988).

Past research has primarily been conducted in regions of high relative humidity. In such regions, LVPD (evaporative demand) is generally lower than LVPD in regions of low relative humidity. There is little information on how woody landscape plants respond to high energy loads in arid regions. This study investigated energy balance between 2 common landscape surfaces in an arid climate and how surface energy balance influenced gas exchange and water use of 3 ornamental shrub species in each surface.

\section{Materials and Methods}

This experiment was conducted at a Utah State University research farm in Logan, Utah $\left(41^{\circ} 45^{\prime}\right.$ $\mathrm{N}, 111^{\circ} 49^{\prime} \mathrm{W}$; elevation $1,341 \mathrm{~m}[4,400 \mathrm{ft}]$ ). To represent a nonvegetative, urban surface, soil in a $9.1 \times 18.3 \mathrm{~m}(30 \times 60 \mathrm{ft})$ area was covered with $0.15 \mathrm{~m}$ ( 6 in.) of coarse pine-bark mulch. Bare soil

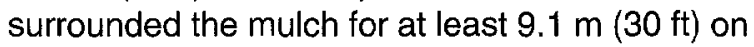
each side. Twenty-four $\mathrm{m}$ ( $80 \mathrm{ft}$ ) north of the mulch site was an area of established Kentucky bluegrass (Poa pratensis) that was used to represent a vegetative surface. The vegetative surface was $30.5 \times 30.5 \mathrm{~m}(100 \times 100 \mathrm{ft})$ with several large trees and small shrubs on the perimeter. Between these 2 surfaces was a $6.0 \times 30.5 \mathrm{~m}(20 \times 100 \mathrm{ft})$ section of Kentucky bluegrass and a 6-m (20-ft)wide asphalt road. In May 1995, established skunkbush sumac (Rhus trilobata), spreading euonymus (Euonymus kiautschovicus 'Manhattan'), and redosier dogwood (Cornus sericea) in $7.5 \mathrm{~L}$ ( 2 gal) containers were purchased from a local nursery. All shrubs were held under standard nursery practices in a common area for 2 weeks until placed into treatment areas.
Throughout the growing season, all shrubs remained in their containers. To moderate root-zone temperature, holes were dug in each surface treatment area such that the top of each container would be slightly below grade. Holes in each surface treatment plot were centrally located such that each hole was at least $4.5 \mathrm{~m}(15 \mathrm{ft})$ from the outer edge of the treatment surface and $3 \mathrm{~m}(10 \mathrm{ft})$ from another hole. In mid-May 1995, 4 shrubs of each species were randomly placed in each surface treatment. Single shrubs of each species were grouped together to form a replicate, with 4 replicates for each treatment. Throughout the growing season, all shrubs were well watered to avoid drought stress.

A weather station was placed over each surface and programmed to continuously collect data from mid-June until late August 1995. Incoming short-wave radiation was measured with a pyranometer sensor (Model LI-200SZ, LI-COR, Inc., Lincoln, Nebraska). Soil heat flux $\left(S_{F}\right)$ and soil temperature $\left(T_{0}\right)$ were measured with a heatflow transducer (Radiation-Energy Balance Systems Inc., Seattle, Washington) and a $0.38 \mathrm{~mm}$ (0.014 in.) diameter copper-constantan thermocouple (Omega Engineering Inc., Stamford, Connecticut), respectively. Sensors were placed $1 \mathrm{~cm}(0.4 \mathrm{in}$.) below the soil for mulch and immediately below the thatch layer for turf. At the time of installation, soil surrounding the mulch sensors was saturated with water and allowed to drain to field capacity. Temperature of each surface $\left(T_{s}\right)$ was measured with an infrared thermometer (Everest InterScience Inc., Fullerton, California) placed $0.5 \mathrm{~m}(1.6 \mathrm{ft})$ above each surface. Air temperature $\left(T_{A}\right)$ and relative humidity $\left(R_{H}\right)$ were measured with a combination temperature and humidity probe placed $2 \mathrm{~m}(6.5 \mathrm{ft}$ ) (Model CR500, Campbell Scientific Inc., Logan, Utah) and $0.3 \mathrm{~m}$ (1 ft) (Model HMP-35A, Vaisala Inc., Helsinki, Finland) above each surface. All sensors were scanned every 10 seconds and averages were recorded every 30 minutes with a data logger (Model CR10, Campbell Scientific Inc., Logan, Utah).

Dawn-to-dusk measurements of leaf temperature $\left(T_{L}\right)$, stomatal conductance $\left(G_{S}\right)$, and shrub water loss were performed on June 22 and 29 , and August 8 and 27, 1995. On the evening be- 
fore measurements were taken, all shrubs were removed from treatments and irrigated until water drained from the bottom of the container. All containers were allowed to drain until the next morning when containers were enclosed within 2 plastic bags and sealed with duct tape. Each shrub was weighed before and after all measurements were taken, and gravimetric water loss was calculated as the difference between before and after weights. Leaf temperature was measured with a handheld infrared thermometer (Everest InterScience Inc., Fullerton, California), and $\mathrm{G}_{\mathrm{S}}$ was measured with a steady-state porometer (Model 1600, LI-COR Inc., Lincoln, Nebraska). Measurements began near 9:00 A.M. (Mountain Daylight Time) on each study day. Four sun and 2 shade leaves on each shrub were measured. Measurements began on the first replicated species group in mulch and then continued in turf. This cycle was repeated until all 4 species replicates were measured. Following the measurement of the fourth shrub group, the cycle was repeated after about an hour break. Data collection ceased about 6:00 P.M. Throughout each study day, each shrub was measured 5 or 6 times. After all experiments ended, each shrub was defoliated and total leaf area was measured with a leaf area meter (Model Cl-203, CID Inc., Vancouver, Washington). Daily shrub water loss for each study day was calculated by dividing gravimetric water loss $\left(\mathrm{cm}^{3}\right)$ by total leaf area $\left(\mathrm{cm}^{2}\right)$ and expressing in $\mathrm{mm}$ (in.).

On 3 dates (August 9, 25, and 31, 1995), between 1:00 and 3:00 P.M., midday photosynthetic rate $\left(P_{N}\right)$ was measured with a portable photosynthesis system (Model 6200, LI-COR Inc., Lincoln, Nebraska) in closed mode (Mitchell 1992). Measurements began on the first replicated species group in mulch and then continued in turf. This cycle was repeated until all 4 species replicated were measured. For each shrub, 3 fully expanded, full-sun leaves were measured and 3 observations were taken per leaf.

Typical surface energy balance was caiculated using weather data from a 5-day period (July 17 to 21,1995 ). Thirty-minute means for short-wave radiation, and $S_{F}, T_{S}, T_{O}, T_{A}$, and $R_{H}$ for each surface were averaged and plotted against time of day. Standard errors (SE) of the means of 2:00 P.M. observations (time of average greatest short-wave radiation) were calculated for each climatic variable. Due to similarities of results among the 4 sample dates, only dawn-to-dusk data from August 27 will be discussed. Leaf-toair vapor pressure difference was calculated using saturated vapor pressure at leaf temperature and ambient vapor pressure (Jones 1992). Stomatal conductance, $T_{L}$, and LVPD were plotted against time of day. Cycle means were exposed to analysis of variance appropriate for a split-plot design (SAS 1989). If significant differences were found, means were separated by Fisher's Least Significance Difference Procedure $(\alpha=0.10)$. Stomatal conductance and LVPD data were analyzed by regression analysis and linear curves were fitted to the data (SAS 1989). Midday $P_{N}$ results were similar on each day; therefore, only data from August 31 will be discussed. Gravimetric water-loss means for August 27 and midday $P_{N}$ for August 31 were exposed to analysis of variance appropriate for a split-plot design (SAS 1989). If significant differences were found, means were separated by Fisher's Least Significance Difference Procedure $(\alpha=0.10)$.

\section{Results}

Climate conditions over the course of the 5-day weather sample period (July 17 to 21,1995 ) were characterized by sunny and clear skies (Figure 1a). Surface properties of turf and mulch affected microclimates and soil energy balance. Soil heat flux below turf peaked at 59.5 watts $\mathrm{m}^{-2}$, while $S_{F}$ for mulch peaked at 36.6 watts $\mathrm{m}^{-2}$ (Figure 1a). Soil temperature for turf was also greater than $T_{0}$ for mulch (Figure 1b). Soil temperature below turf was $11 \%$ to $35 \%$ greater than $T_{0}$ below mulch. Surface temperatures of turf and mulch were also different (Figure 1b). Maximum mulch $\mathrm{T}_{\mathrm{S}}$ reached $62.6^{\circ} \mathrm{C}\left(144.6^{\circ} \mathrm{F}\right)$, while maximum turf $\mathrm{T}_{\mathrm{S}}$ was $31.7^{\circ} \mathrm{C}\left(89.1^{\circ} \mathrm{F}\right)$.

Above each surface, the microclimate differed more at $0.3 \mathrm{~m}$ than at $2.0 \mathrm{~m}$ (Figure 1c, d). Air temperature over each surface at $2 \mathrm{~m}$ was nearly the same until about 4:00 PM. After that time, $\mathrm{T}_{\mathrm{A}}$ at $2 \mathrm{~m}$ over turf was cooler than $\mathrm{T}_{\mathrm{A}}$ over mulch (Figure $1 \mathrm{c}$ ). At the $0.3 \mathrm{~m}$ height, $\mathrm{T}_{\mathrm{A}}$ over mulch 


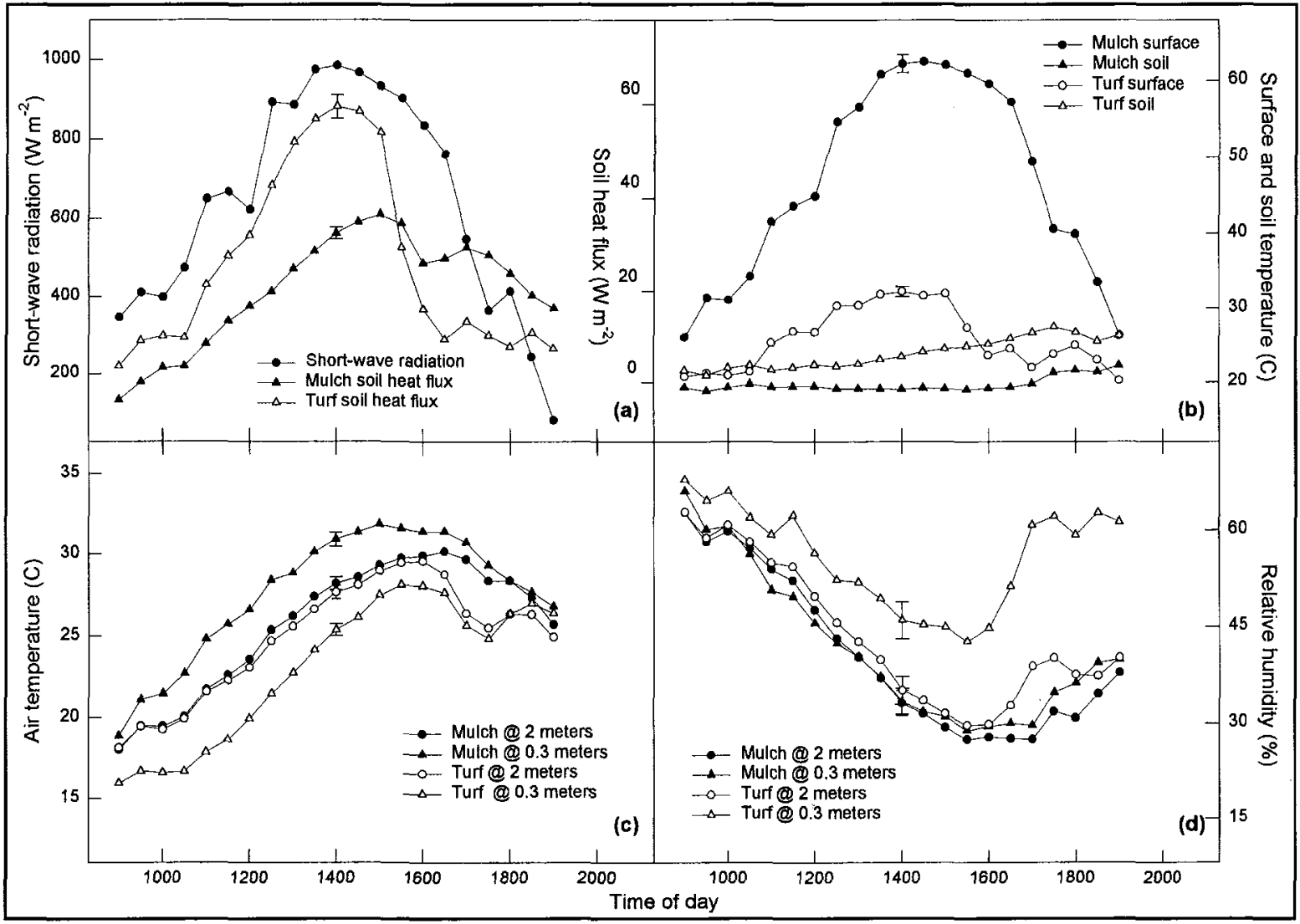

Figure 1. Short-wave radiation (a), soil heat flux (a), surface temperature (b), soil temperature (b), and air temperature (c) and relative humidity (d) at $0.3 \mathrm{~m}(1 \mathrm{ft})$ and $2 \mathrm{~m}(6.5 \mathrm{ft})$ for turf and pine-bark mulch surfaces averaged over 5 days (July 17 to 21, 1995). Vertical bars represent standard errors (SE) of 2:00 P.M. mean. SE is smaller than symbol when error bar is not shown.

was greater than $T_{A}$ over turf throughout each day (Figure 1c). Except over turf at $0.3 \mathrm{~m}, \mathrm{R}_{\mathrm{H}}$ over each surface was similar at each height (Figure 1d). Throughout the day, $R_{H}$ over turf at $0.3 \mathrm{~m}$ was up to $120 \%$ greater than $R_{H}$ at the other 3 recording locations.

During August 27, 1995, dawn-to-dusk measurements, climatic conditions were typical for a summer day in the Intermountain West. Skies were clear and sunny (total short-wave irradiance of 24.1 $\left.\mathrm{MJ} \mathrm{m}^{-2}\right), \mathrm{T}_{\mathrm{A}}$ was warm $\left(32.6^{\circ} \mathrm{C}\left[\left(90.6^{\circ} \mathrm{F}\right]\right.\right.$ maximum and $\left.11.9^{\circ} \mathrm{C}\left[53.4^{\circ} \mathrm{F}\right]\right)$ minimum), wind speed was moderate (1 to $4.4 \mathrm{~m} \mathrm{~s}^{-1}$ [2.2 to $9.8 \mathrm{mph}$ ]), and $\mathrm{R}_{\mathrm{H}}$ was low (15.4\% minimum and $66.6 \%$ maximum). For each species, $T_{L}$ and evaporative demand (LVPD) were generally higher over mulch (Figure $2 \mathrm{~d}-\mathrm{i})$. Highest $T_{L}$ for plants in mulch was $33.3^{\circ} \mathrm{C}$ $\left(92^{\circ} \mathrm{F}\right)$ versus $30.8^{\circ} \mathrm{C}\left(87.4^{\circ} \mathrm{F}\right)$ for those in turf (Figure 2d-f). Leaf-to-air vapor pressure differences for shrubs in mulch were $13 \%$ to $40 \%$ greater than LVPD for shrubs in turf (Figure $2 g-i$ ).

Stomatal conductance did not differ greatly between surfaces for $E$. kiautschovicus and $C$. sericea but did for $R$. trilobata. In general, $\mathrm{G}_{\mathrm{s}}$ for $E$. kiautschovicus and $C$. sericea over turf and mulch were not different throughout the day (Figure $2 \mathrm{~b}, \mathrm{c}$ ). However, $\mathrm{G}_{\mathrm{S}}$ for $R$. trilobata shrubs over turf was up to $32 \%$ greater than $G_{s}$ for $R$. trilobata over mulch (Figure 2a). Throughout the day, $G_{S}$ for $R$. trilobata was greater than $G_{S}$ of the other species, regardless of surface treatment (Figure $2 \mathrm{a}-\mathrm{c}$ ). For each species, $\mathrm{G}_{\mathrm{S}}$ decreased as LVPD increased (Figure $3 a-b$ ). This inverse relationship was found for each surface treatment. 


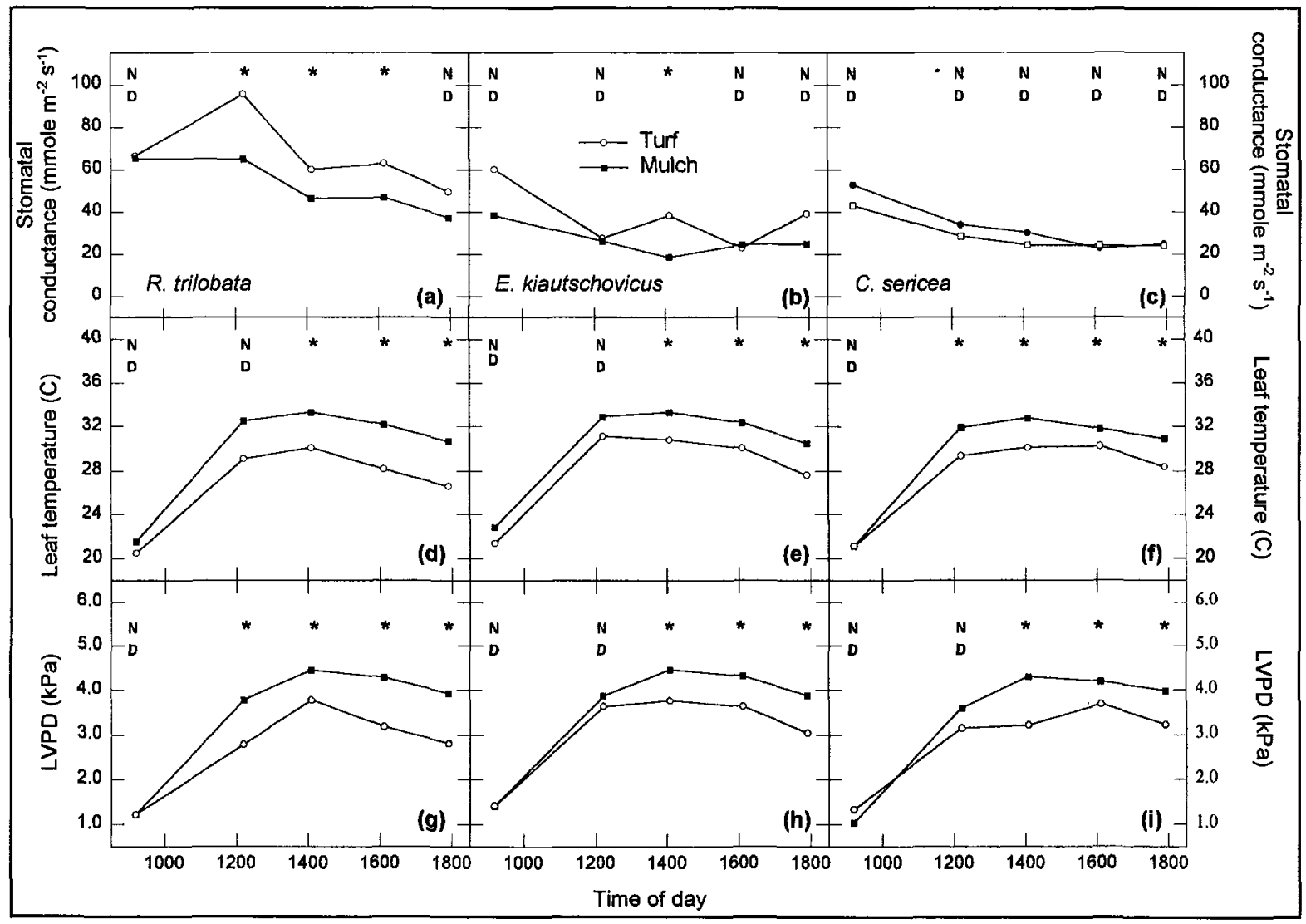

Figure 2. Dawn-to-dusk stomatal conductance, leaf temperature, and leaf-to-air vapor pressure difference (LVPD) for containerized $R$. trilobata $(a, d, g)$, E. kiautschovicus $(b, e, h)$, and $C$. sericea $(c, f, i)$ growing over turf and pine-bark mulch on August 27, 1995. (Each point is the mean of 24 measurements. Means between treatments are not different [ND] or different [*] [LSD, $\alpha=0.10]$.)

Treatment effects on water loss for each species were not evident except for $R$. trilobata (Table 1). Water loss for $R$. trilobata in turf was $16 \%$ greater than water loss in mulch. Rhus trilobata had greater $\mathrm{G}_{\mathrm{s}}$ (Figure $2 \mathrm{a}-\mathrm{c}$ ), and water loss was approximately $50 \%$ greater than $E$. kiautschovicus or $C$. sericea (Table 1), regardless of surface.

Shrub midday $P_{N}$ differed between surfaces and species. August 31, 1995, data show that $R$. trilobata and $E$. kiautschovicus over turf had higher $P_{N}$ than shrubs over mulch (Table 1). Photosynthetic rates for $R$. trilobata and $E$. kiautschovicus over turf were $54 \%$ and $75 \%$ greater, respectively, than $\mathrm{P}_{\mathrm{N}}$ over mulch. However, for $C$. sericea there was no difference in $P_{N}$ between surface treatments (Table 1).

\section{Discussion}

Increased heating of the mulch surface compared to the turf surface was due to the lack of evaporative cooling and the partitioning of absorbed solar radiation. Solar radiation reaching turf was dissipated as latent heat via turf transpiration, which reduced $T_{s}$ when compared to mulch (Figure $1 b$ ). Zajicek and Heilman (1991) found relative and absolute differences in $T_{S}$ for turf and pine-bark mulch that were similar to those in our study. Soil heat flux and $T_{0}$ below mulch were lower when compared to turf (Figure $1 a, b)$ indicating that solar radiation reaching the mulch surface was not conducted into the soil. Mulch acted as insulation and prevented energy from penetrating into the soil. Instead, radiation reaching the mulch surface was re-radiated as long-wave radiation. 


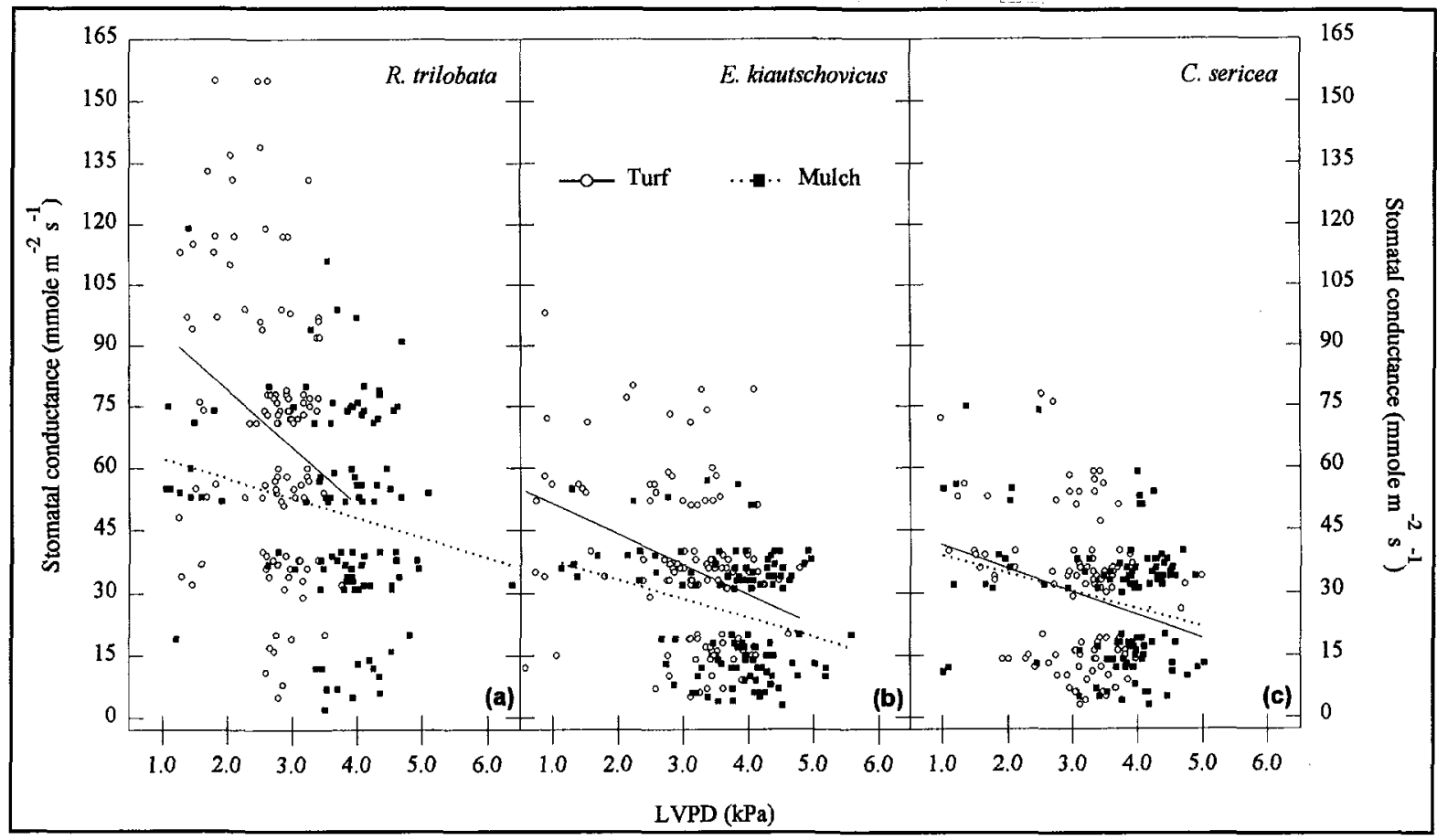

Figure 3. Actual and predicted values for effect of leaf-to-air vapor pressure difference (LVPD) on stomatal conductance $\left(G_{s}\right)$ for 3 containerized shrub species growing over turf and pine-bark mulch (August 27, 1995). Predicted regression line equations are followed by $r^{2}$ values and significance for the equation.

R. trilobata over turf (a): $\mathrm{G}_{\mathrm{s}}=107.1085-13.9866 \mathrm{x}, r^{2}=0.0610, P=0.0081$

R. trilobata over mulch (a): $G_{s}=67.0408-4.7672 x, r^{2}=0.0371, P=0.0512$

E. kiautschovicus over turf (b): $\mathrm{G}_{\mathrm{s}}=58.5610-7.2548 \mathrm{x}, r^{2}=0.1211, P=0.0001$

E. kiautschovicus over mulch (b): $G_{s}=42.4121-4.6014 x, r^{2}=0.0762, P=0.0037$

C. sericea over turf (c): $\mathrm{G}_{\mathrm{s}}=47.1067-5.619 \mathrm{x}, r^{2}=0.0595, P=0.0122$

C. sericea over mulch (c): $\mathrm{G}_{\mathrm{s}}=43.3024-4.3090 \mathrm{x}, r^{2}=0.0680, P=0.0059$

Higher sensible heat flux from the mulch surface was evident since $T_{A}$ and $R_{H}$ at $0.3 \mathrm{~m}$ were different than those recorded at $2 \mathrm{~m}$ (Figure 1c, d). Some researchers have recorded weather data at the height of approximately $2 \mathrm{~m}$ (Miller 1980; Zajicek and Heilman 1991; Kjelgren and Clark 1992), while others have not specified a recording height (Halverson and Potts 1981; Whitlow and Bassuk 1987, 1988). Our research indicates that microclimates at $0.3 \mathrm{~m}$ can be substantially different than microclimates at $2 \mathrm{~m}$. At $0.3 \mathrm{~m}$ there would be less air mixing than at $2 \mathrm{~m}$ (Monteith and Unsworth 1990); therefore, $\mathrm{T}_{\mathrm{A}}$ and $R_{H}$ would be more closely linked to the surface than $T_{A}$ and $R_{H}$ at $2 \mathrm{~m}$. Differences between surface climatic variables at $2 \mathrm{~m}$ may also be minimized by the size and spacing of the surfaces. A larger surface area and greater distance between surfaces may have resulted in climatic variables that were less of a mixture of the 2 surfaces (Oke 1983; Monteith and Unsworth 1990). Because mulch $T_{A}$ was higher and $R_{H}$ was lower at $0.3 \mathrm{~m}$ than at $2 \mathrm{~m}$, shrubs growing over the mulch surface were exposed to greater evaporative demand (higher LVPD) than shrubs growing over the turf surface.

High LVPD for shrubs over turf and mulch surfaces resulted in partial stomatal closure (Farquhar 1978; Turner et al. 1984) for shrubs over each surface (Figure $3 a-c$ ). Greater heating of the mulch 
Table 1. Water loss and midday photosynthetic rate for containerized $\boldsymbol{R}$. trilobata, $E$. kiautschovicus, and $C$. sericea growing over turf and pine-bark mulch.

\begin{tabular}{|c|c|c|c|c|}
\hline \multirow[b]{3}{*}{ Species } & \multirow{2}{*}{\multicolumn{2}{|c|}{$\begin{array}{l}\text { Water loss } \\
\text { Aug. } 27,1995 \\
\text { mm (in.) }\end{array}$}} & \multirow{2}{*}{\multicolumn{2}{|c|}{$\begin{array}{l}\text { Photosyn. rate } \\
\text { Aug. } 31,1995 \\
\text { umole } \mathrm{m}^{-2} \mathrm{~s}^{-1}\end{array}$}} \\
\hline & & & & \\
\hline & Turf & Mulch & Turf & Mulch \\
\hline R. trilobata & $3.3(0.13) a$ & $2.8(0.11) b^{y}$ & $23.8 \mathrm{a}$ & $11.1 \mathrm{~b}$ \\
\hline $\begin{array}{l}\text { E. kiautscho- } \\
\text { vicus }\end{array}$ & $1.5(0.06)$ & $1.3(0.05)$ & $11.5 \mathrm{a}$ & $2.9 \mathrm{~b}$ \\
\hline C. sericea & $1.5(0.06)$ & $1.2(0.05)$ & 9.4 & 6.8 \\
\hline \multicolumn{5}{|l|}{ Significance } \\
\hline Species & \multicolumn{2}{|l|}{$* * *$} & \multicolumn{2}{|c|}{$* * *$} \\
\hline $\begin{array}{l}\text { Treatment } \\
\text { Species } x\end{array}$ & \multicolumn{2}{|l|}{ NS } & \multicolumn{2}{|c|}{$\star \star \star \star ~$} \\
\hline treatment & \multicolumn{2}{|l|}{$\star *$} & \multicolumn{2}{|c|}{$* * *$} \\
\hline
\end{tabular}

${ }^{x}$ NS, ${ }^{* *},{ }^{* * *}$ : Nonsignificant or significant at the $5 \%$ or $1 \%$ level by F-test, respectively.

YMeans between columns having the same letter are not different (LSD, $\alpha=0.10$ ).

surface resulted in more long-wave radiation being intercepted by shrubs over mulch and increased LVPD compared to shrubs over turf (Figure $2 \mathrm{~g}-\mathrm{i}$ ). However, $R$. trilobata reacted differently to microclimate conditions than $E$. kiautschovicus and $C$. sericea. For the latter 2 species, as LVPD increased above $4 \mathrm{kPa}, \mathrm{G}_{\mathrm{s}}$ decreased to less than $40 \mathrm{mmole}^{-2} \mathrm{~s}^{-1}$ (Figure $3 \mathrm{~b}$, c). Even as LVPD fell below $4 \mathrm{kPa}$ in the evening, $G_{S}$ for $E$. kiautschovicus and $C$. sericea increased only slightly (Figure 2b, c, h, i). Because of similar $\mathrm{G}_{\mathrm{s}}$, water loss for $E$. kiautschovicus and $C$. sericea was not different between turf and mulch treatments (Table 1). For most of the day, $\mathrm{G}_{\mathrm{S}}$ of $R$. trilobata over turf was greater than $\mathrm{G}_{\mathrm{S}}$ over mulch (Figure 2a). Higher LVPD for $R$. trilobata shrubs over mulch resulted in greater stomatal closure (Farquhar 1978; Turner et al. 1984) than $R$. trilobata shrubs over turf (Figure 2a). Higher $G_{s}$ rates for $R$. trilobata over turf also resulted in greater water loss (Table 1). Although $R$. trilobata had comparable LVPD as E. kiautschovicus and C. sericea throughout the day (Figure $2 g-i$ ), $G_{S}$ for $R$. trilobata was greater (Figure 2a, b). When LVPD increased to $4 \mathrm{kPa}$ or greater, $\mathrm{G}_{\mathrm{S}}$ for $R$. trilobata remained well above the $40 \mathrm{mmole} \mathrm{m}^{-2} \mathrm{~s}^{-1}$ rate of E. kiautschovicus and $C$. sericea (Figure 3a).
Surface properties also appear to influence midday $P_{N}$ of $R$. trilobata and $E$. kiautschovicus but not $C$. sericea (Table 1). Because a decrease in $P_{N}$ is expected with a decrease in $G_{S}$ (Hinckley et al. 1978), reduced $P_{N}$ was anticipated for $R$. trilobata over mulch compared to $R$. trilobata over turf (Table 1). However, because $G_{S}$ for $E$. kiautschovicus over mulch and turf is similar (Figure $2 b$ ), greater $P_{N}$ for $E$. kiautschovicus over turf was unexpected. High leaf temperature, high LVPD, and stomatal closure can limit photosynthetic rate in woody plants (Hinckley et al. 1978; Kartusch 1983; Turner et al. 1984), and this appears to be the case for $R$. trilobata and $E$. kiautschovicus over mulch and for $C$. sericea over turf and mulch. Why midday $P_{N}$ for $E$. kiautschovicus over turf and mulch were similar, despite lower $\mathrm{G}_{s}$ rates for $E$. kiautschovicus over mulch, is unknown.

Our results differ from those found by Zajicek and Heilman (1991), who report greater water loss for containerized crape myrtle (Lagerstroemia indica) cultivars over pine-bark mulch compared to cultivars over turf. Increased water loss for crape myrtle over pine-bark mulch may be the result of factors not found in our study. Weather conditions in their study were similar to those during our study except that $R_{H}$ was greater during their experiment than $R_{H}$ during ours (Zajicek and Heilman 1991; Figure 1d). Therefore, plants in their study were subjected to lower LVPD through more of the day than we observed. This allowed crape myrtle stomata to remain open longer and increased water loss. Another factor could be that stomata of crape myrtle are less sensitive to LVPD than species used in our study (Turner et al. 1984).

\section{Conclusions}

Microclimates over turf and pine-bark mulch surfaces were different because of dissimilar surface properties. Mulch acted as insulation and prevented energy from reaching the soil. Consequently, the mulch surface was hotter and re-radiated more energy than the turf surface. The increase in available energy increased $T_{A}$ and decreased $R_{H}$ over the mulch surface. In contrast, turf dissipated energy through transpirational 
cooling and allowed more energy to reach the soil. Therefore, $T_{A}$ was lower and $R_{H}$ was greater over the turf surface. These data show that at $0.3 \mathrm{~m}$, the microclimate over a pine-bark mulch surface is more extreme than the microclimate over turf. These data also demonstrate that plant canopies $2 \mathrm{~m}$ above a surface (such as trees) would be exposed to a mix of the surrounding microclimate variables and not just the microclimate produced by the surface below.

In an arid climate, gas exchange and water loss by containerized $R$. trilobata, E. kiautschovicus, and $C$. sericea were influenced differently by each surface. Rhus trilobata was less sensitive to LVPD than $E$. kiautschovicus or $C$. sericea. This was indicated by higher $\mathrm{G}_{\mathrm{s}}$ and water loss for $R$. trilobata than $E$. kiautschovicus and $C$. sericea under similar climatic conditions. Both $R$. trilobata and $C$. sericea are native Utah species. Each can be found in moist sites; however, $R$. trilobata can also be found in very dry sites (Welsh et al. 1987). Euonymus kiautschovicus is similar to $C$. sericea in that it is native to humid, understory sites in China (Steward 1950; Dirr 1990). Although R. trilobata is native to arid habitats and is considered drought tolerant (Taylor's Guide to Water-Saving Gardening 1990), under nonlimiting soil water conditions R. trilobata used more water than E. kiautschovicus and $C$. sericea, species considered less drought tolerant. Similar results with mesquite (Prosopis alba) and live oak (Quercus virginiana) trees, considered drought tolerant and nondrought tolerant, respectively, have also been reported (Levitt et al. 1995). Greater water loss from $R$. trilobata indicates that a drought-tolerant shrub species can use more water than nondrought tolerant species if soil water is plentiful. Our research indicates that under nonlimiting soil water conditions, $R$. trilobata may be better suited than E. kiautschovicus and $C$. sericea to sustain growth under the high $\mathrm{T}_{\mathrm{A}}$ and low $\mathrm{R}_{H}$ found in urban climates throughout the Intermountain West.

\section{Literature Cited}

Choudhury, B.J., and J.L. Monteith. 1986. Implications of stomatal response to saturation deficit for the heat balance of vegetation. Agric. For. Meteorol. $36: 215-225$.
Dirr, M.A. 1990. Manual of Woody Landscape Plants: Their Identification, Ornamental Characteristics, Culture, Propagation and Uses. Stipes Publishing Co., Champaign, IL. 1007 pp.

Doll, D., J.K.S. Ching, and J. Kaneshiro. 1985. Parameterization of subsurface heating for soil and concrete using net radiation data. Boundary-Layer Meteorol. 32:351-372.

Farquhar, G.D. 1978. Feedforward responses of stomata to humidity. Aust. J. Plant Physiol. 5:787800.

Halverson, H.G, and D.F. Potts. 1981. Water requirements of honeylocust (Gleditsia triacanthos $f$. inermis) in the urban forest. USDA For. Serv. Res. Pap. NE-487.

Hinckley, T.M., R.G. Aslin, R.R. Aubuchon, C.L. Metcalf, and J.E. Roberts. 1978. Leaf conductance and photosynthesis in four species of the oakhickory forest type. For. Sci. 24:73-84.

Jarvis, P.G., and K.G. Mcnaughton. 1986. Stomatal control of transpiration: Scaling up from leaf to region. Adv. Ecol. Res. 15:1-49.

Jones, H.G. 1992. (2nd ed.) Plants and Microclimate. A Quantitative Approach to Environmental Plant Physiology. University Press, Cambridge, England. $428 \mathrm{pp}$.

Kartusch, B. 1983. The photosynthetic capacity of two shrubs (Spiraea spec. and Ligustrum vulgare) in a city biotop. Flora. 173:223-232.

Kim, H.H. 1992. Urban heat island. Int. J. Remote Sensing 13:2319-2336.

Kjelgren, R.K., and J.R. Clark. 1993. Growth and water relations of Liquidambar styraciflua $\mathrm{L}$. in an urban park and plaza. Trees. 7:195-201.

Kjelgren, R.K., and J.R. Clark. 1992. Microclimates and tree growth in three urban spaces. J. Environ. Hort. 10:139-145.

Levitt, D.G., J.R. Simpson, and J.L. Tipton. 1995. Water use of two landscape tree species in Tucson, Arizona. J. Amer. Soc. Hort. Sci. 120:409-416.

Miller, D.R. 1980. The two-dimensional energy budget of a forest edge with field measurements at a forest-parking lot interface. Agricult. Meteorol. 22:53-78.

Mitchell, C.A. 1992. Measurement of photosynthetic gas exchange in controlled environments. HortScience 27:764-767.

Monteith, J.L., and M.H. Unsworth. 1990. Principles of Environmental Physics. Edward Arnold, London, England. $291 \mathrm{pp}$.

Oke, T.R. 1983. Boundary Layer Climates. Methuen and Co.. New York, NY. 372 pp. 
Potts, D.F., and Herrington. 1982. Drought resistance adaptations in urban honeylocust. J. Arboric. 8:75-80.

SAS Institute Inc. 1989. SAS/STAT User's Guide, Version 6, 4th ed., Vol. 1. SAS Institute, Inc., Cary, NC. 943 pp.

Steward, A.N. 1958. Manual of Vascular Plants of the Lower Yangtze Valley, China. International Academic Printing Co., Tokyo, Japan. $621 \mathrm{pp}$.

Taylor's Guide to Water-Saving Gardening. 1990. Chanticleer Press, New York, NY. 447 pp.

Turner, N.C., E.D. Schulze, and T. Gollan. 1984. The responses of stomata and leaf gas exchange to vapour pressure deficits and soil water content. Oecologia 63:338-342.

Welsh, S.L., N.D. Atwood, L.C. Higgins, and S. Goodrich. 1987. A Utah Flora. Brigham Young University, Provo, UT. 894 pp.

Whitlow, T.H., and N.L. Bassuk. 1988. Ecophysiology of urban trees and their management: The North American experience. HortScience 23:542-546.

Whitlow. T.H., and N.L. Bassuk. 1987. Trees in difficult sites. J. Arboric. 13:10-17.

Zajicek, J.M., and J.L. Heilman. 1991. Transpiration by crape myrtle cultivars surrounded by mulch, soil, and turfgrass surfaces. HortScience 26: 1207-1210.

Acknowledgements. This research was supported by the Utah Agricultural Experiment Station, Utah State University, Logan, Utah 84322-4810. Approved as journal paper no. 7070 .

\section{${ }^{1}$ Graduate Research Assistant \\ ${ }^{2}$ Assistant Professor \\ ${ }^{3}$ Associate Professor \\ Utah State University}

Department of Plants, Soils, and Biometeorology Logan, UT 84322-48201

Zusammenfassung. Wir untersuchten die Energiebilanz von vegetativen und nicht-vegetativen Oberflächen und den Gasaustausch von drei Gehölzen, die über jeder Oberfläche wuchsen.Während einer einwöchigen Periode Mitte Juli wurden die Daten der eingehenden Kurzwellenstrahlung, die Oberflächen- und Bodentemperatur und die Hitzeentwicklung des Bodens bei Torf- oder Rindenmulchabdeckung gesammelt. Die Lufttemperatur und die relative
Luftfeuchtigkeit wurden an zwei Höhen über jeder Oberfläche ebenfalls gemessen. Die Mulchoberfläche und die Lufttemperatur waren während des ganzen Tages wärmer und die Bodentemperatur unter dem Mulch kühler als bei der Torfoberfläche. Die relative Luftfeuchtigkeit variierte mit der Höhe über dem Torf, jedoch lag jeder Wert oberhalb dem bei Mulch. Für den Großteil des Tages war die Bodenwärmeentwicklung über dem Torf größer als bei Mulch. Es wurden in einer Messung von morgens bis abends die Stomataöffnung und Leitfähigkeit, die Blatttemperatur und der Wasserverlust für getopfte Rhus trilobata, Euonymus kiautschovicus "Manhattan" und Cornus sericea gemessen. Die Büsche in Mulch hatten höhere Blattemperatur und größeren Dampfdruckdifferenz als die Büsche in Torf. Rhus trilobata hatte größere Stomata-Leitfähigkeit und Wasserverlust in Torf als in Mulch. Aber bei Euonymus und Cornus sericea waren keine großen Differenzen bei der Leitfähigkeit und dem Wasserverlust zwischen den unterschiedlichen Oberflächen zu bemerken. Die Photosyntheserate zur Mittagszeit war im allgemeinen bei Büschen über Torf am größten. Der Gasaustausch der Büsche wich ab in Abhängigkeit davon, wie die Stomata auf den Blatt/Luft-Dampfdruck über jeder Oberfläche reagierten.

Resumen. Se investigó el balance de energía de superficies vegetativas y no vegetativas y el intercambio de gases para tres especies de arbustos en cada superficie. Durante un periodo de una semana, a mediados de Julio, se registraron las entradas de radiación de onda corta, la temperatura de la superficie y del suelo, y el flujo de calor del suelo para superficies de pasto y mulch de corteza de pino. También se midieron la temperatura del aire y la humedad relativa a dos alturas sobre cada superficie. A través de cada día, las temperaturas del mulch superficial y del aire fueron más calientes y la temperatura del suelo debajo del mulch fue más fría, que las del pasto. La humedad relativa varió con la altura arriba del pasto, pero esto fue comparable con el mulch. Para la mayor parte del día, el flujo de calor del suelo debajo del pasto fue mayor que el del mulch. Se hicieron mediciones de la mañana a la tarde del comportamiento estomatal, temperatura de la hoja y pérdida de agua en contenedor para el zumaque de zorrillo (Rhus trilobata), euonymus disperso (Euonymus kiautschovicus "Manhatta") y cornejo (Cornus sericea). Los arbustos en mulch tuvieron mayores temperaturas de la hoja y mayores diferencias de presión de vapor de la hoja al aire que los arbustos con pasto. Rhus trilobata tuvo mayor respuesta estomatal y pérdida de agua en pasto que en mulch. Sin embargo, para E. kiautschoivicus y C.sericea, no hubo diferencias en respuesta estomatal o pérdida de agua entre los tratamientos superficiales. La tasa fotosintética de mediodía fue generalmente mayor para los arbustos sobre pasto. El intercambio de gas de los arbustos difirió de acuerdo a como los estomas respondieron a la diferencia de presión de vapor de la hoja sobre cada superficie. 